\section{Condensation of Water in the Atmosphere}

In Nature of December 16, p. 938, it is stated: "A number of workers, notably Defant, Köhler, Niederdorfer, claim to have shown that the volume of droplets in the atmosphere are most frequently integral multiples of some standard minimum size". The "law" claimed by Defant and Köhler is much more interesting than this statement implies.

In 1905 Defant measured raindrops : the smallest drops were less than $1 / 40$ th of a milligram in weight, while the largest were more than 100 milligrams,

The outstanding feature of the result which Defant claimed to have established was that the most frequent sizes (weights) of raindrops were in the ratio $1: 2: 4: 8: 16$, etc. Defant found two such series. In the principal series the unit was $0.115 \mathrm{mgm}$. , and in the secondary series it was $0.35 \mathrm{mgm}$. or three times as heavy. Thus the two series can be represented as $1 x, 2 x, 4 x, 8 x$, etc. and $3 x, 6 x, 12 x$, $24 x$, etc. where $x$ is $0.115 \mathrm{mgm}$. This immediately suggests three things :

(i) Primary drops tend to be of the same size.

(ii) Large drops tend to be formed by coalescence of drops rather than by continuous growth.

(iii) Gravity is an effective operating agent in the formation of compound drops.

If one had (i) and (ii) alone, then drops would tend to be $1,2,3,4$, etc., times the primal drop ; that is, the integral multiple law would hold. The "law of 2" necessitates a sorting of the drops by the action of gravity. Such a sorting by gravity is indeed inescapable: rain does fall on places not themselves in cloud. I remember mentioning this twenty-five years ago in a letter to the late Prof. Poynting about his note on the rate of fall of cloud drops in the first edition of the volume on "Heat" in the Text Books of Physics series, and in later editions he referred to Defant's work.

These measurements by Defant were made with raindrops. Köhler, many years later, measured the sizes of drops in fogs and clouds, and came to the conclusion that for these drops, also, the same "law of 2" held. These drops have a diameter 100 times less than Defant's raindrops, and weights 1,000,000 times less". At that time I wrote : "Independent testimony-dare one hope from Scotland-is required of the 'law of 2' before it can be included among the established facts of meteorology". It appears from the article in NATURE of December 16 that not only does Scotland stand where it did, but that the testimony is not yet complete.

8, Hurst Close, N.W.11.

E. GoLd.

Dec. 19.

${ }^{1}$ Nature, 119, 654, April 30, 1927.

\section{Measurements of Submarine Daylight}

In the course of the last nine years Poole and Atkins ${ }^{1}$ have developed a very ingenious method for measuring the intensity of the daylight penetrating into the sea by means of alkali-metal photo-cells, using a delicate balance method for measuring the very weak photo-currents. The many vagaries of the photo-cells make measurements with this contrivance rather difficult to any but trained experimenters. In order to find a simpler and less expensive method of measuring submarine daylight we have used the novel 'Sperrschicht' selenite photo-cells due to Dr. B. Lange. As these cells give a photo-current several hundred times more intense than the most sensitive of the alkali cells, it is possible to use an ordinary pointer galvanometer, or some similar instrument, for the observations, while at the same time they are simpler and more easily manipulated by relatively untrained observers. The instrument used for our measurements gave a deflection of one scale-unit for $3 \cdot 76 \times 10^{-7}$ amperes and could be read to within 0.1 scale-unit. Another advantage of the Lange cell is its broad maximum of sensibility between 4500 and $5500 \mathrm{~A}$., that is, with its centre near the minimum of light-extinction found by Knudsen for coastal water at $5100 \mathrm{~A}$. The narrow region of maximum sensibility characteristic of the potassium cell is situated much nearer the violet end of the spectrum.

We have been using the Lange cell, protected from the water by a thick disc of plate-glass, externally roughened, within a strong box of brass, into which a rubber-insulated cable holding two $0.75 \mathrm{~mm} .^{2}$ copper wires for the photo-current passes from below. Read. ings taken, first when the instrument was being lowered into the sea, then repeated at the same depths while it was being raised to the surface, agreed closely inter se and showed characteristic variations in the transparency, apparently due to plankton or to detritus suspended in the water. On a clear day in August the submarine daylight in the central Baltic Sea could be measured by this simple contrivance down to a depth of 50 metres. With the cell inverted, its sensitive surface facing downwards, the light scattered upwards could be measured down to 25 metres.

Two similar instruments combined with a registering galvanometer have for the last three months been used for recording continuously the variations in submarine daylight in the Gullmar Fjord, here suspended from our observation pier, one in 15 metres depth and the other cell one metre below the surface. We believe the instrument will become useful to oceanographers for making rapid surveys of the transparency of the water at different depths and also for studying the relationship between the light-factor and the flowering of the phyto-plankton. A more detailed report is being published in Meddelanden frain Göteborgs Högskolas Oceanografiska Institution.

\section{Bornö Station.}

Hans Pettersson. Svante Landberg.

\section{Nov.}

${ }_{1} J$. Marine Biol. A88oc., 14, $177 ; 1926 ; 15,485 ; 1928 ; 16$, 297 ; 1929. Also Biol. Bulletin, 65, 317 ; 1933.

\section{Structure of Collagen Fibres and the Point of Attack by Proteolytic Enzymes}

Some recent work by Bergmann and his colleagues has shown that the action of trypsin on gelatin gels is limited to the surface of the gel ${ }^{1}$ and that the action on fresh collagen fibres is limited to the cut ends of the fibres ${ }^{2}$, the enzymes having apparently no power to attack the fibres from their sides. Some observations made here on the penetration of bacteria into putrefying hide suggest that the same generalisation can be applied to the bacterial proteases.

It has been observed that the organisms penetrate the experimental pieces most readily from their cut edges and from the inner or 'flesh' surface, penetration from the outer or hair surface being very slow. According to Kaye ${ }^{3}$, the reticular fibres of skin, which hold the collagen fibres and fibre bundles together, 